\title{
GEOTOURISM ATTRACTIONS OF HORMUZ ISLAND, IRAN
}

\author{
Mohsen RANJBARAN* \\ School of Geology, College of Science, University \\ of Tehran, Tehran, Iran, e-mail: m.ranjbaran@ut.ac.ir \\ Syed Mohammad ZAMANZADEH \\ Department of Geography, University of Tehran, \\ Tehran, Iran, Tehran, Iran, e-mail: zamanzadeh@ut.ac.ir \\ Farzad SOTOHIAN \\ Faculty of Natural Resources, Department: Environmental Science \\ Department, University of Guilan, Iran, e-mail: farzad_sotohian@yahoo.com
}

\begin{abstract}
Citation: Ranjbaran, M., Zamanzadeh, S.M. \& Sotohian, F. (2020). GEOTOURISM ATTRACTIONS OF HORMUZ ISLAND, IRAN. GeoJournal of Tourism and Geosites, 28(1), 232-245. https://doi.org/10.30892/gtg.28118-465
\end{abstract}

\begin{abstract}
Hormuz Island is a salt dome situated in the Persian Gulf waters near the mouth of Hormuz Strait in Hormuzgan province, at 8 kilometers distance from Bandar Abbas. The island is elliptical, and its rock is mostly of the igneous and often volcanic type. Hormuz is one of the most beautiful Islands of the Persian Gulf due to its geological phenomena and related landforms. This island is a mature salt diapir with great mineralogical and lithological diversity. In this research, we focused on fieldwork, which included data gathering and taking photographs and also a review of the published papers and books. The main geotourism attractions of the island include various landforms resulted from differential erosion, as well as very attractive geomorphologic structures such as rocky and sandy beaches, sea caves, colorful salt domes, coral reefs, etc. Besides the geological and geomorphological sites of the region, the ancient and cultural features are also potential attractions for tourism development on the island. Given its natural assests, territorial planning and developed infrastructure, Hormuz Island could be proposed and exploited as a geopark.
\end{abstract}

Key words: Geotourism, Hormuz Island, the Persian Gulf, geosite salt dome, cultural tourism

\section{INTRODUCTION}

Nowadays, tourism is considered as the most successful industry in the world since it will be followed by significant results and achievements like rich foreign exchange earnings, development of scientific-cultural relations, the improvement of direct and

\footnotetext{
* Corresponding author
} 
indirect jobs as well as showing the stability and safety of the country (Dowling \& Newsome, 2006; Dowling, 2010; Newsome \& Dowling, 2010). Geotourism tries to organize and make geological attractions of the earth targeted and prevent the destruction of the works by human beings through creating and defining geoparks (Newsome \& Dowling, 2010). Preservation of the environment and its perspectives, keeping it intact and abstaining from interfering with changing the earth's face are some of the main objectives of geotourism. Geotourism is the subset of sustainable tourism, aiming at preserving tourism resources in the destinations (McKeever \& Zouros, 2005; McKeever et al., 2010). In today's world, tourism has a wide approach to geotourism.

As one of the subcategories of the tourism industry, geotourism is considered significantly important, since the diversity of geological structures in different points of Iran attracts many geologists as well as the geology and nature lovers from all over the world every year. Based on the environment of knowledge, all materials are divided into geotic, biotic and anthropic categories (Martínez-Torres, 1994). People visit morphological features in the center and edge of the island for a diversity of reasons; the major one is probably the relaxation in nature and uses the wonders of creation (Dóniz-Páez et al., 2011). With our nature-centered tourism, we have many experiences, interactions with people and nature as well as lifestyles (Fanni \& Rezazadeh, 2018).

In the meantime, Iran's southern islands like Hormuz, Qeshm, Larak, Hengam, and Lavan are of great importance (Yazdi et al., 2014). Geological diversity is from the assets and geological identities of a country that should be protected. A part of geological diversity is considered as the geological heritage called Geosite. Geosites are the places with outstanding examples of geological history, prominent geological processes contributing to the development of landforms, shapes and globally valuable geological forms. Hormuz Island is known as the geologic pearl of the Persian Gulf that is globally famous due to its great variety of rocks and minerals (Zakeri \& Habib, 2013a, $2013 \mathrm{~b})$. This diversity of geological structures caused attracting many domestic and international tourists every year. There are many valuable attractions such as beautiful landscapes around the island, ocher mine, coral reefs, rocky shores, sea caves, various shapes and material of coastal banks, native vegetation, resident wildlife on the island and some cultural and historical features. Hormuz Island is known as Paradise of Geologists for its diverse and unique geologic and biologic phenomena and its high potential for becoming a excellent geotourism pole in the Persian Gulf area.

In addition to the geological and natural attractions of the area, the ancient and cultural features of the island, this island has a great potential from ecotourism standpoint due to a variety of its fauna and flora as well (Amrikazemi, 2002, 2004, 2013; Amrikazemi \& Mehrpooya, 2006). This paper aims to identify the geological structures of Hormuz Island and its specific features as geotourism attractions.

\section{MATERIALS AND METHODS}

Descriptive-analytical and field methods have been used for analyzing the geotourism attractions of Hormuz Island. Documents, reports, geological maps (with a scale of 1:100000), photographs were analyzed. But this research is mainly based on data collected during the field trips in Hormuz Island.

\section{STUDY AREA}

Hormuz Island is situated in the Strait of Hormuz at the junction of the Persian Gulf and the Gulf of Oman $\left(56^{\circ} 25^{\prime}\right.$ to $56^{\circ} 30^{\prime}$ East longitude and $27^{\circ} 2^{\prime}$ to $27^{\circ} 5^{\prime}$ North latitude), in the south of Hormuzgan province, Iran. Hormuz Island lies between Bandar Abbas in the northwest and Qeshm and Lark Islands in the southwest (Figure 
1a, b). The coastline length is about $31 \mathrm{~km}$. The large part of the island is uneven and represents various landforms. The highest point of the island is 228 meters and the lowest point is zero. If Hormuz Island is divided into two northern and southern halves, then the whole southern half is hilly and rocky, and its northern half is centrally rugged and the height decreases to the north and the plain surfaces are smooth. Hormuz Island is an oval-shaped whose small diameter is $5.5 \mathrm{~km}$ and a large diameter ranges between 7.5 to $9 \mathrm{~km}$. Its area is about $42 \mathrm{~km}^{2}$. Most parts of the island represent different parts of a salt dome (Talaei Hassanlouei \& Rajabzadeh, 2018). Geomorphologically, considering the effect of the forming geological deposits and related tectonic structures, the island and its limited boundaries may be divided into the following units:

a) Uneven ground b) plains and c) Beaches. About $69 \%$ of the southern part of the island is rugged and covered with evaporative deposits. The south part of the island is mainly composed of Hormuz evaporates and salt diapir.
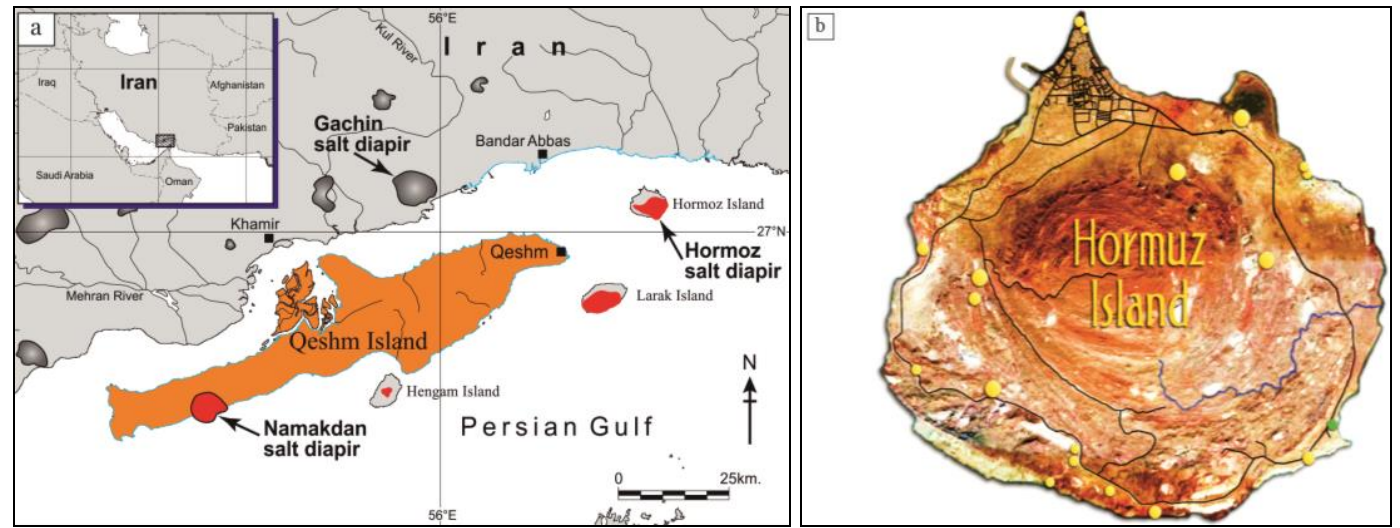

Figure 1. Location of Hormuz Island. a) at the mouth of Hormuz Strait, b) Hormuz Island

\section{GEOLOGY OF HORMUZ ISLAND}

The Hormuz Island is a salt diapir, in which the dominant petrography type is volcanic rocks. This island is the location of a specific formation, Hormuz Series with great lithological diversity (Talaei Hassanlouei \& Rajabzadeh, 2018).

The Hormuz series on the island includes salt rocks and gypsum in addition to the masses and pieces of igneous and sedimentary rocks. It is significant that the stratigraphic rows of Hormuz series in Iran's salt domes have a cluttered nature, and no row can be detected in it. The stratigraphic column of the Hormuz series in southern Iran was determined by Ahmadzadeh Heravi et al., (1990) as follows (from top to bottom): 1) purple sandstone, coarse-grained sandstone and shale; 2) volcanic, tuff and agglomerate, partially gypsum; 3) dolomite, lime, shale and occasionally rhyolite; 4) salt rock (Talbot, 1988; Talbot et al., 2009a, 2009b). The island is one of the major and most famous salt domes of the Persian Gulf, whose formation has started from the upper Precambrian era.

Regarding construction, Hormuz is almost entirely concentric and based on the studies of Elyasi et al., (1977), from inside to outside, it includes evaporative rocks, iron structures and Miocene-Pliocene sediments. There have been two volcano phases in the geological history of Hormuz, the first of which has been alkaline (including decomposed Basalts and Diabase) and probably occurred before the Permian era; and the latter was acidic (including rhyolite, rhyodacite, and trachyte) and related to the former Triassic era (Ala, 1974; Moein Vaziri, 1996). Aghajari and Mishan formations are other clastic formations of the island from Cenozoic era. The Mishan Formation is mainly composed of 
gray marl and clayey limestone,and Aghajari Formation is mostly composed of limestone and red marls. In the central part of the island, between the Aghajari Formation in the south and alluvial zones and slope debris in the north, the Hormuz series is out-bounded.

Materials resulted from the destruction of various layers of Hormuz series extend in the form of low-volume, low-thickness alluvial zones and slope debris in the northern parts of the island (Figure 2a, b, C). Magmatic activities in the Hormuz have been in both forms of output and intrusive rocks. Most of the lava has rhyolite or rhyodacite composition, and some have trachytic compounds and rarely basalt (Moein Vaziri, 1996).
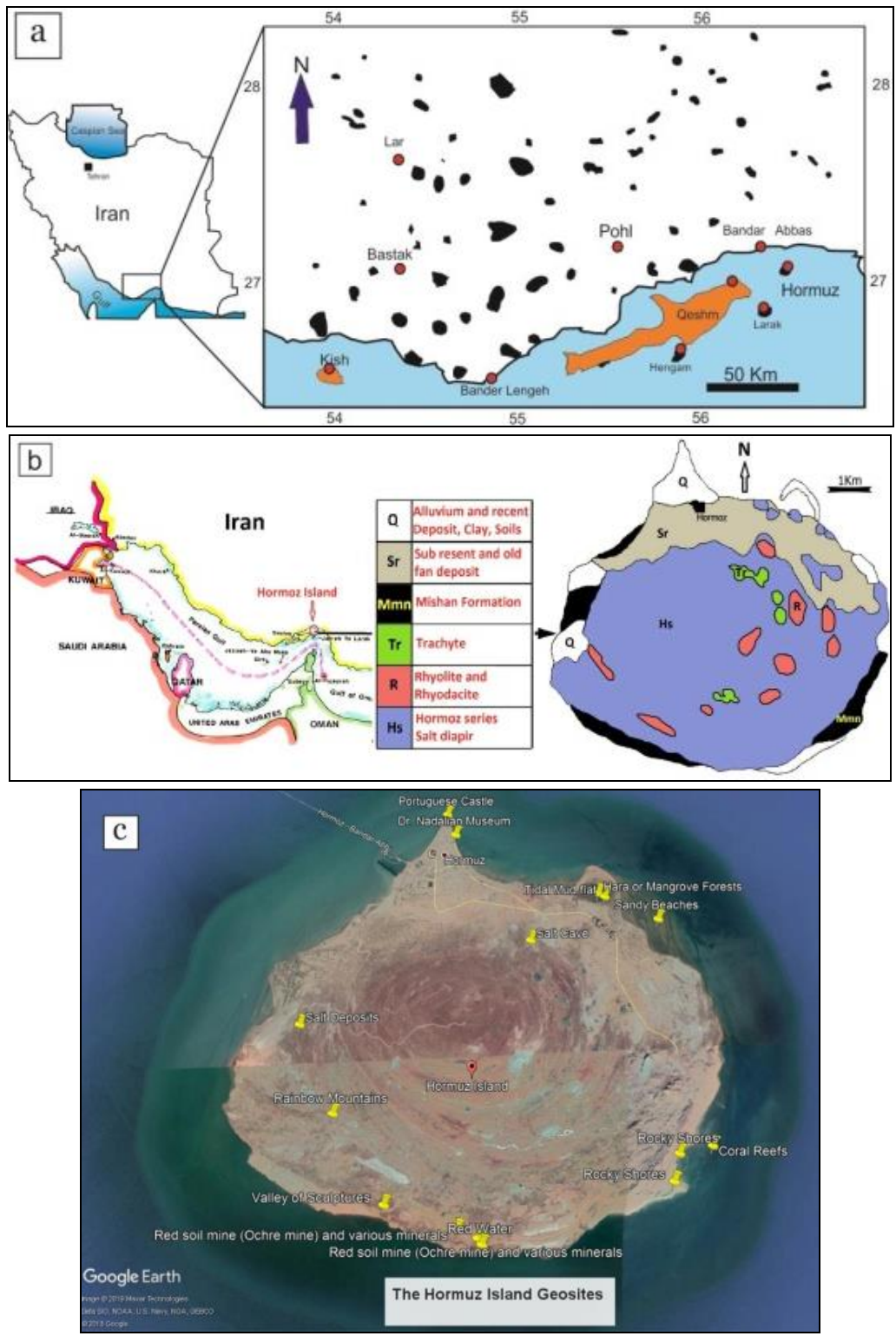

Figure 2. a) Geography of the salt diapirs in south of Iran and Hormuz Island (Talaei Hassanlouei \& Rajabzadeh, 2018), b) Simplified geological map of Hormuz Island (Faramarzi et al., 2015) and c) the Hormuz Island geosites 
Most volcanic rocks of Hormuz Island have been weathered. The rhyolites have maintained their original qualities more or less. In rhyolitic tuffs, minerals such as quartz phenocrysts remained fresh and feldspars have been completely sericitized.

Basalts have maintained their physical properties regarding color and sometimes texture and structure; however, in mineralogy terms, their degradation and destruction have been so advanced that they can hardly be recognized. The volcanic masses of the island are observed as a relatively strong cap on the salt masses. Volcanic tuffs of Hormuz Island are distinguishable with their white color far away from other igneous and sedimentary rocks of the island (Figure $3 \mathrm{a}, \mathrm{b}$ ).
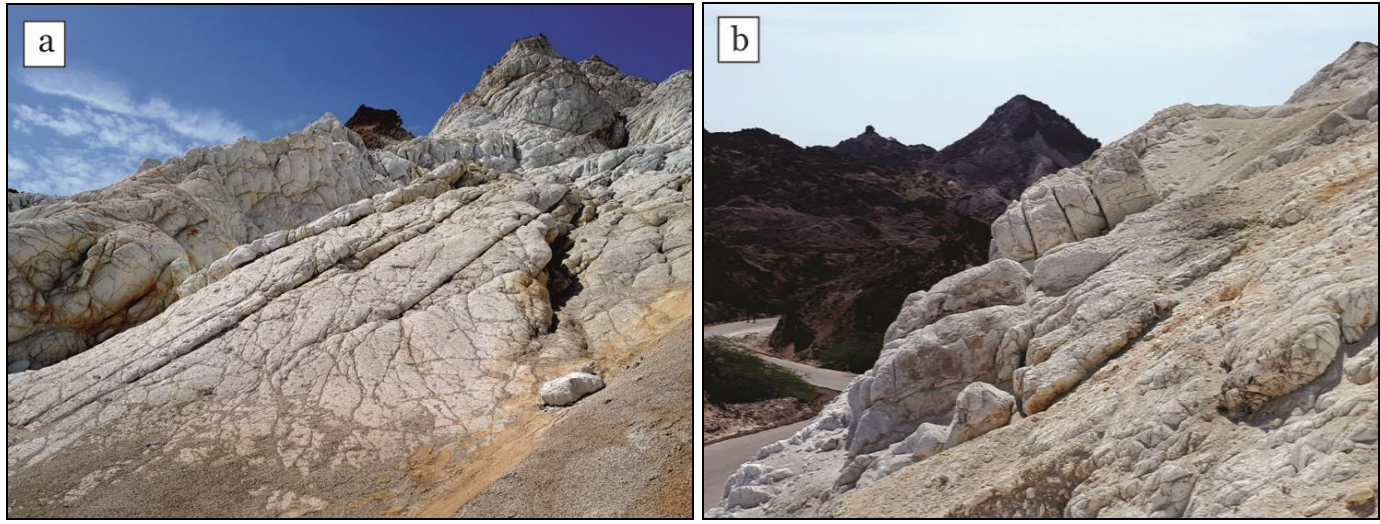

Figure 3. a) Piggy back features in severely jointed rhyolitic rocks on the Hormuz Island

b) Extremely weathered light-colored rhyolitic rocks (in the foreground)

\section{GEOTOURISM ATTRACTIONS OF HORMUZ ISLAND}

Hormuz Island as the pearl of the Persian Gulf is known because of the different geology and mineralogy of the ore which are other attractions on the island geomorphology for people interested in science (Zakeri \& Habib, 2013a). Much of the island is the salt dome. This salt dome occupies about 69 percent of the total area and covers the southern part of the island (Talaei Hassanlouei \& Rajabzadeh, 2018). There is a considerable volume of volcanic and evaporative rocks on the island. The high solubility of salt rock compared to the resistance of igneous rocky finally has created a rough surface and erosion of Hormuz salt dome, sharp topography and salt caves, especially in the central part in the west of the island (Bruthans et al., 2006). The colorful valleys have been developed in the southern part of the island due to the mineralization processes as well as the dissolution of the rocks of the igneous deposits. Moreover, the land boundary of the island with seawater has created several beaches (Amrikazemi, 2002, 2004, 2009, 2013; Amrikazemi \& Mehrpooya, 2006). Considering the lithology, sedimentology and slope topography, three types of shoreline can be distinguished in different parts of the island, including sandy beaches, mudflats and rocky shore. Among the mentioned shorelines, the sandy beaches are the most attracting geomorphosites due to ease of accessibility and beautiful landscape especially in sunset. Also, the ancient monuments of the island like the Portuguese Castle and other old buildings, can be referred to. Each of the attractions of the island's geotourism will be described below.

\section{Salt Deposits}

The majority of the southern part of the island is a salt dome. Intense solubility and erosion of evaporative rocks, in particular, salt rocks, have created various forms of deposits including karrens (Figure 5a), caves (Figure 4a), salt filled pounds (Figure 5b) 
all of which represent attractive landscapes for tourists especially for their outstanding dissolution forms and halite crystals. With salt dissolution at altitudes, the streams flowing from the domes of the salt dome downstream have brought them down, laid flat in the slabs and developed the salt plain. The most marvellous landform of this island is seen where the main road of the island enters into salt dome landform.

About five caves are totally found on the island and all of them have been developed by dissolution and fall of the salt layers and their ceilings and floors are covered with white salt crystals in the cauliflower form.

In one of the southern parts of the island, a very a magnificent salt outcrop with an approximate height of 30 meters is observed in the form of a wall (Figure $4 \mathrm{a}, \mathrm{b}$ ). The surface of this colorful salt wall is adorned by regular vertical threads, indicating the effect of water erosion resulted from atmospheric rainfalls in the area (Figure $5 \mathrm{a}, \mathrm{b}$ ).
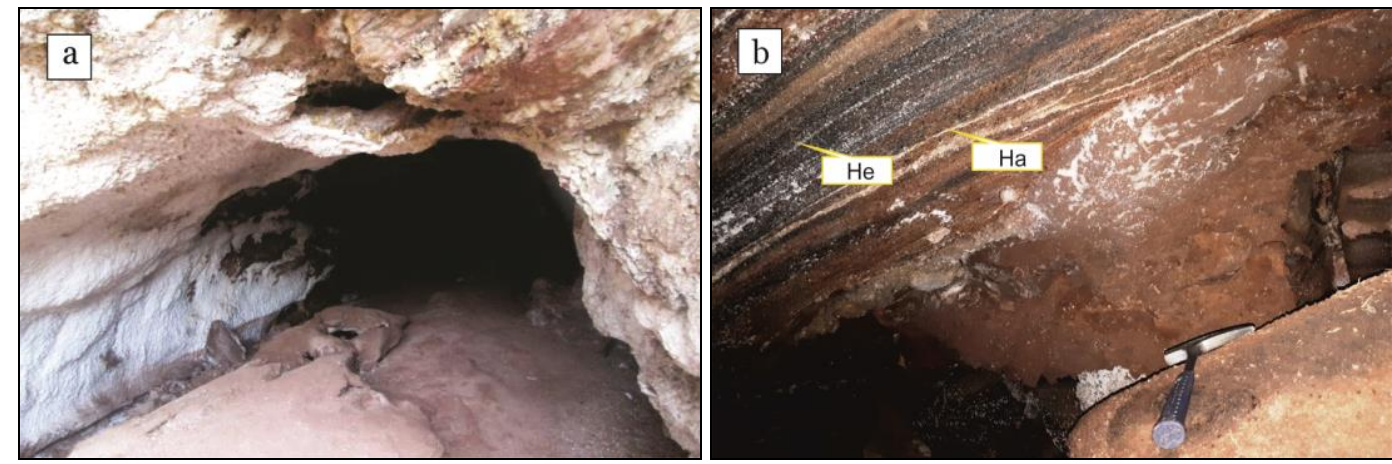

Figure 4. a) Entrance of Cave in the west of Hormuz Island, b) The colorful salt wall composed of alternation of halite (HA) and hematite (HE)

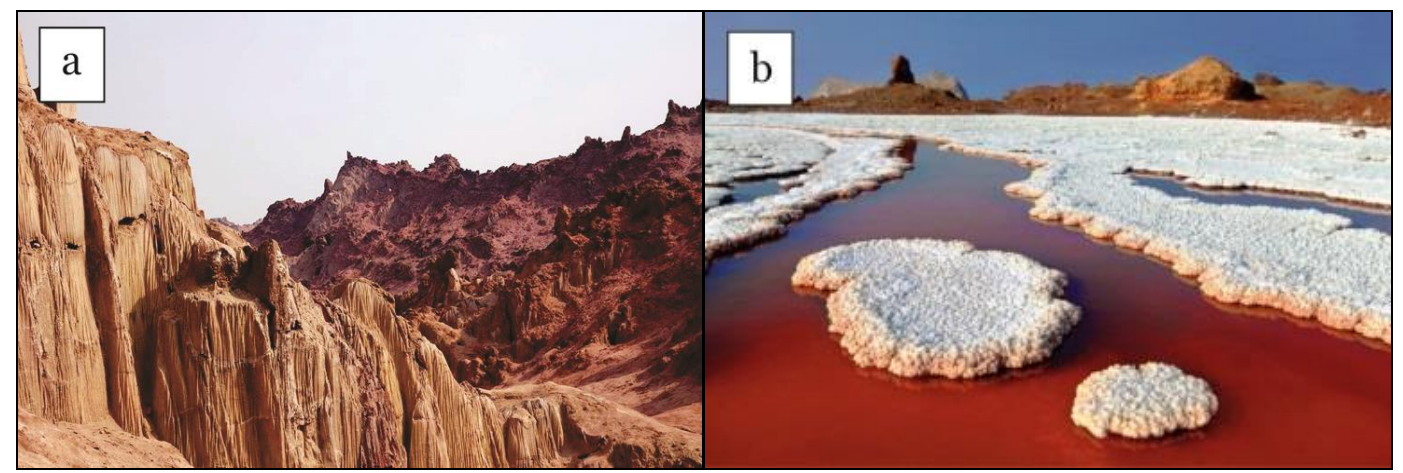

Figure 5. a) Development of vertical karrens on salt outcrops in the foreground,

b) Precipitation of halite crystals resulting in the development of salt plains on the bed of the creeks running out of the salt domes. the water is red due to the presence of $\mathrm{Fe}^{3+}$ ions

\section{Rainbow Mountains}

Due to its diversity and color spectrum, this mountain is one of the main tourist attractions of the island. The colors which are seen in these mountains are due to theresulted from mixing of volcanic and sedimentary rocks as well as the mineralization of hematite. As a result of this mixing and later alteration of rock forming minerals, especially hematite, various minerals, e.g. hematite, goethite and limonite, with various colors are created resulting in the creation of colorful mountains (Yazdi et al., 2013, 2014). 
For example, red, yellow and white (rhyolites) colors are more abundant than other colors (Figure $6 \mathrm{a}, \mathrm{b}$ ). These mountains are located in the southwest coast of Hormuz Island. In addition to the various colors, they have a rugged topography (Figure $6 \mathrm{a}, \mathrm{b}$ ) due to differential resistance of the various rocks against erosion.
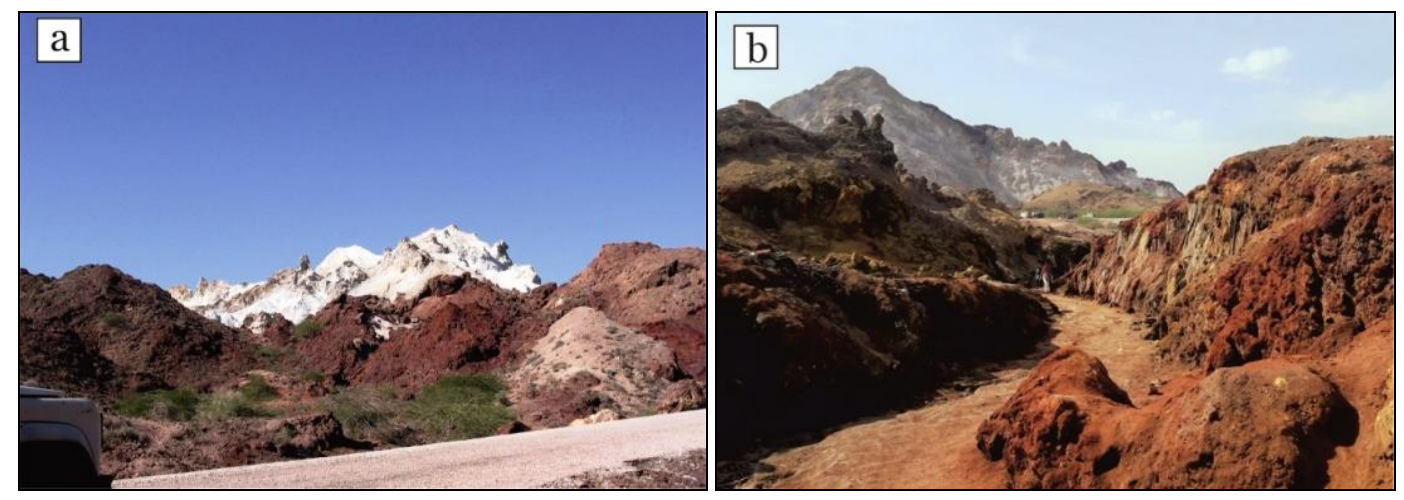

Figure 6. a) a view of rainbow mountains represented by red color (abundance of hematite) in the front and white color (abundance of rhyolite) in the back, b) A valley in the rainbow mountains; the blocks in the front of the image represent less altered volcanic rocks (arrows)

\section{Red soil mine (Ochre mine) and various minerals}

The famous Red Soil Mine (Ochre Mine) of Hormuz Island sparkles in the southernmost beach of the island. The average of ocher soil is $70-75$ wt. $\% \mathrm{Fe}_{2} \mathrm{O}_{3}$ (Samani, 1988; Waltham, 2008). The most abundant form of iron ore formation is observed as the hematite-limonite-oligist (red soil) layers within Hormuz Formation, sometimes in interlayer form with gypsum and anhydrite (Ahmadzadeh Heravi et al., 1990; Talaei Hassanlouei \& Rajabzadeh, 2018; Momenzadeh \& Heidari, 1995; Aqanabati, 2006; Moein Vaziri, 1996). The red soil of the mine is used in paint, cosmetics and ceramic tiles industry, as well as industrial micronized powders, etc. Furthermore, local people use the soil as a facade for their buildings. At present, the ocher soil mine is inactive due to environmental problems. Mineralization in the igneous masses has resulted in the formation of many kinds of minerals with different lithology and various color schemes such as oligist, quartz, gypsum, pyroxene, apatite, pyrite, etc. in different parts of Hormuz Island (Talaei Hassanlouei \& Rajabzadeh, 2018; Mortazavi et al., 2017). This unique diversity in rocks and minerals has created various colors in Hormuz Island and made it a treasure of minerals (Yazdi, 2013). The seawater near the location of hematite mine in the beach is always red in color due to the release of $\mathrm{Fe}^{+}$ions which produces the red color. The soil dissolution in seawater has turned the water red into several meters and has granted a special beauty to the beach (Figure $7 \mathrm{a}, \mathrm{b}, \mathrm{c}$ ).

\section{Valley of Sculptures}

Valley of Sculptures is located in the southwestern part of the island. The forms which are called "the sculptures" are indeed the result of differential erosion which affected conglomerates and breccias. It is another geotourism attraction of Hormuz Island;, rocks with different forms can be observed. Sedimentary rocks have been shaped by erosion and weathering in different forms that look like sculptures of animals like bear and legendary creatures such as dragons. These various shapes have been formed by the erosional action of wind and rain and they adorned Hormuz's dry and hot land in the most beautiful way. The form of rocks indicates that during thousands of years that Hormuz Island has gradually come out of the water, the erosional processes have acted in a way that these sculptures were formed and decorated the surface of the land (Figure 8a, b). 


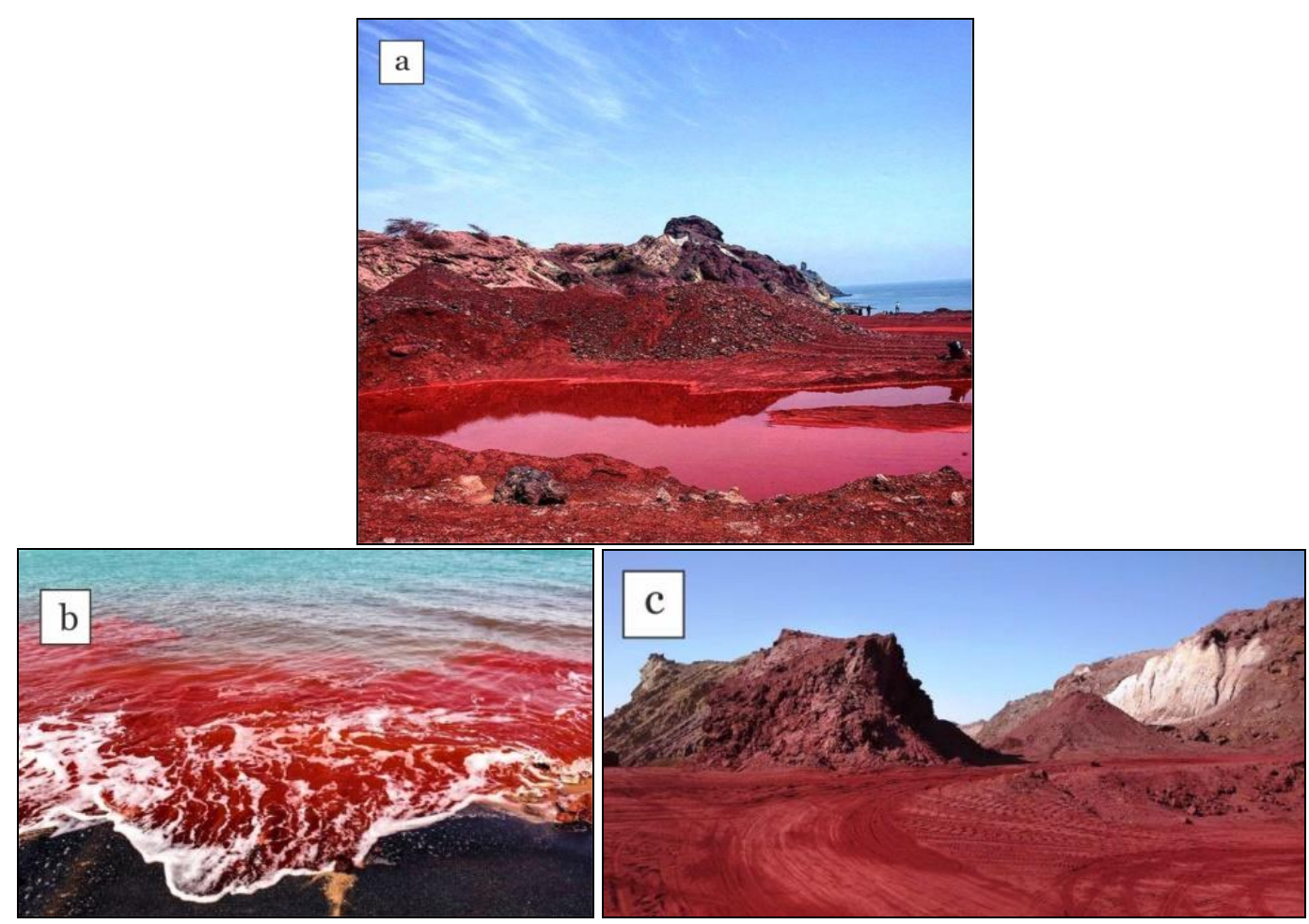

Figure 7. a) Red Soil Mine (Ochre), b) Seawater waves formed with rocks containing red soil has made beautiful scenery, c) boundary of seawater with red soils
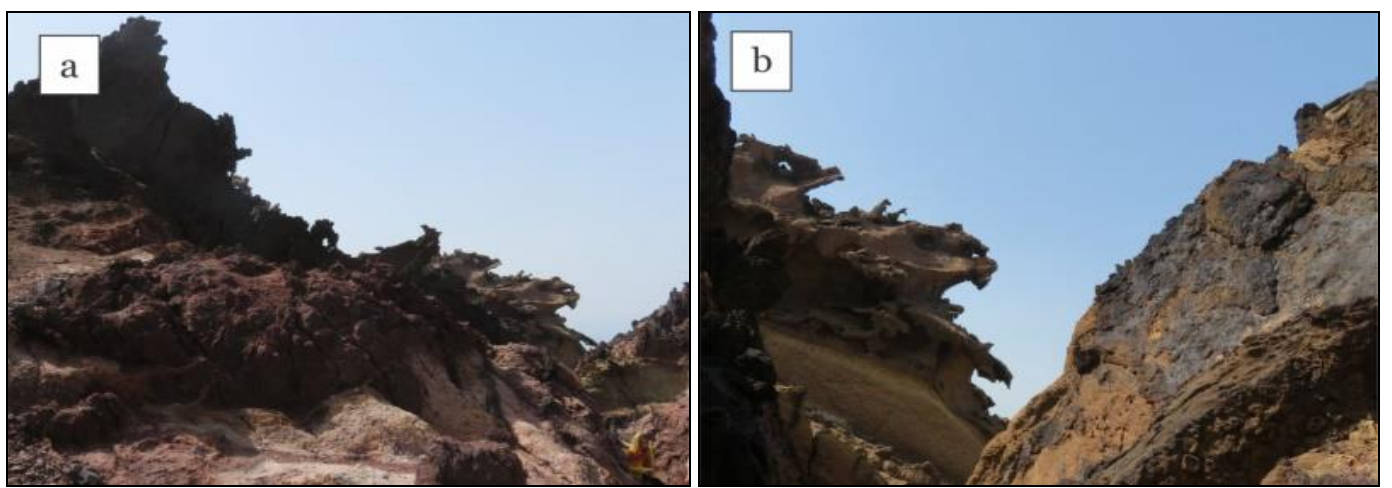

Figure 8. a) a view of some sculpture forms in the sculptures valley,

b) a close up view from an erosional landform-created in "sandstone" deposits in Hormuz Island

\section{Coral Reefs}

On the southeast beaches of the island, coral reef colonies of shallow water have spread on the seafloor. The reefs are composed of the carbonate parts of different organisms such as corals, bivalves, star fishes, fishes and other organisms along with living forms of them. With a great variety of aquatic animals, the coral reefs provide a suitable habitat for turtles. These corals come out of water when the tide occurs, and they represent one of the attractions of Hormuz Island especially for the ecotourists. In these reefs, different species of crabs, gastropods and sea cucumbers are abundant (Figure $9 \mathrm{a}, \mathrm{b}$ ). 


\section{Hara or Mangrove Forests}

Mangrove or Hara Forest, another attraction of Hormuz Island, is seen on the northeast beach. These forests are usually considered as a significant ecotourism site. There are over 60 species of mangroves in the world. The Hara tree is a salt-water plant that is often submerged at high tide. Hara tree's bark has a filtration potential which allows the plant to absorb softened water while eliminating the salt. The tree is a natural water purifier. The Mangrove forests represent an important ecological resource.

Two species of mangrove spread on Hormuz Island. Common types of mangrove on Hormuz Island include Rhizophora macrunata and Avicennia marina (Zahed et al., 2010). The trees of these forests are green all year. Hara forest is the vegetation set including trees and shrubs observed in coastal saline waters in the form of a narrow strip.

Given their suitable conditions, Hara forests are a safe habitat for fish, molluscs, crustaceans and migratory birds from tropical areas (Ghasemi et al., 2010). Hara sets of Hormuz Island are the planting sets lying on a muddy bed. Crabs, gastropods and mudskippers are among the main inhabitants of these areas (Figure 10 a).
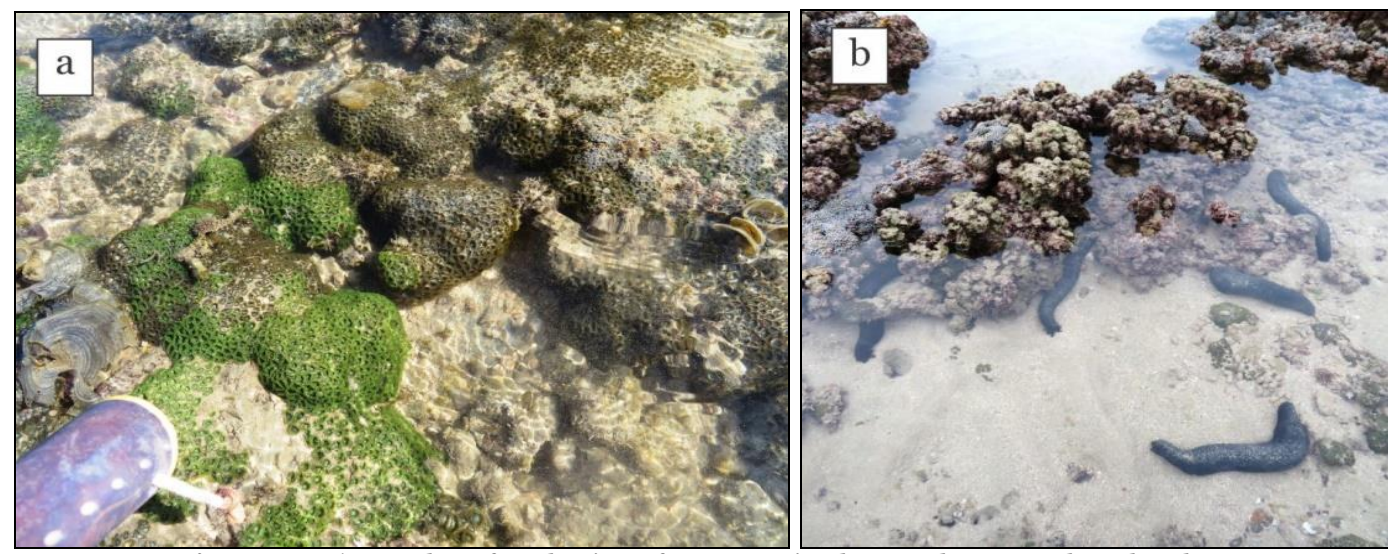

Figure 9. a) Coral reefs colonies of Hormuz in the southeastern beach. They are subaerially exposed in low tide; b) Coral reefs colonies in the same area as (a) along with sea cucumbers (Holothuridea class)

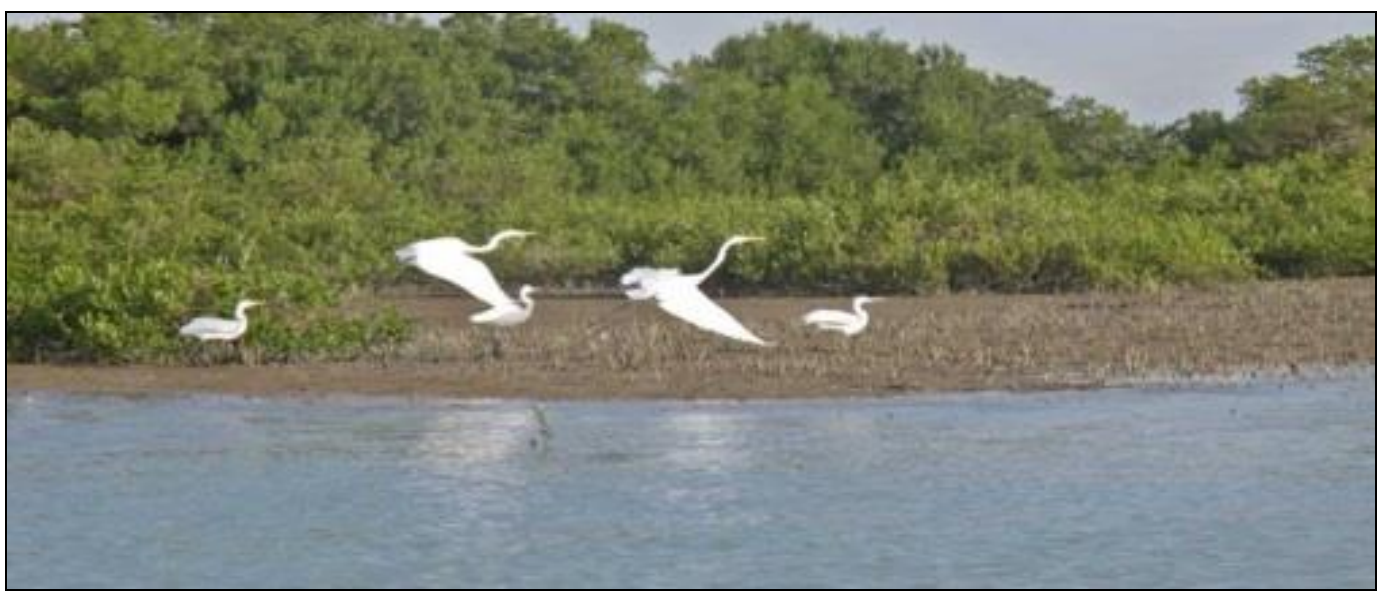

Figure 1o. Planting Hara forests, the habitat of bird and other organisms on the eastern margin of Hormuz Island 


\section{Tidal Mud flat}

A vast, nearly horizontal, marshy or barren area in shorelines that is alternately covered and uncovered by the tide and consists of unconsolidated sediments (i.e., mostly mud) (Bates \& Jackson, 1980). Tidal mud flats with the diversity of different fauna and flora and their various effects on mud flat environments are the other geotourism attraction especially from photography viewpoint. The slopes of the southern beaches are affected by the tidal water hydrologic system the maximum extension of which is more than 4 meters. When the tides occur, the morphology of the fine grained areas will not change because of the cohesion between the mud-sized grains.

Because of the low slope of the coast as well as being protected from sea turbulence and waves, the sedimentary areas are usually rich in organic matter (Mirzabagheri et al., 2018; Noori-Koupaei et al., 2014, 2015). Mudflats of Hormuz Island are located in the eastern and northeastern parts of the island (Bruthans et al., 2006) (Figure 11).

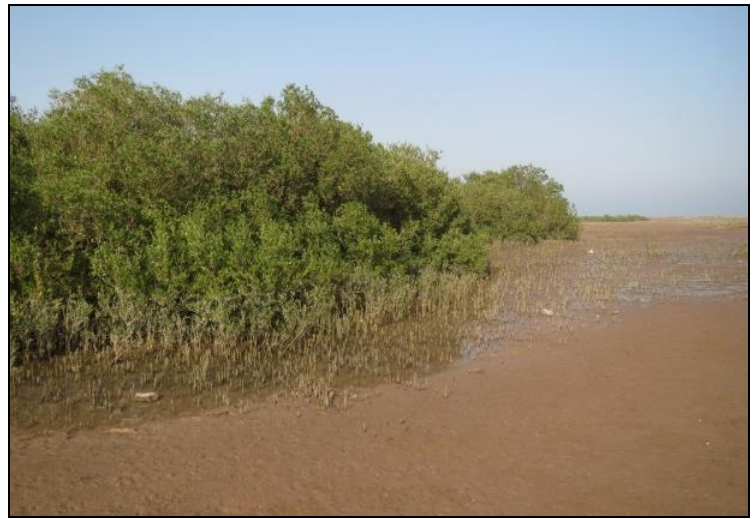

Figure 11. Mudflats near Hara forests in the northern part of Hormuz Island

\section{Sandy Beaches}

This type of beach often extends in the form of narrow strips with about 20 to 30 meters in different parts of the island. From the geomorphological point of view, these beaches encompass the littoral, subtidal and backshore zones each of which is dominated by special flora and fauna assemblages. In sandy beaches, all types of sea birds can usually be observed in all seasons. Such beaches have a high tourist potential. The presence of starfish, sea anemones and digging worms is very noticeable in some part of the beaches (Buschbaum et al., 2012; Luttikhuizen \& Dekker, 2010) (Figure 12, a, b, c).

\section{Rocky Shores}

This type of shores are cliff-dominated ones with or without sandy berms. The sandy berms are usually seen when there is a low tide. In many areas, there are rows of limestone and layers more resistant to water erosion. Rocky shores benefit from coastal biodiversity particularly bivalve species such as oyster and crabs (Zakeri \& Habib, 2013a). Most algae zones of the island can be seen in these areas. These shells are from the oysters, firmly attached to hard surfaces and seen in the middle part of the intertidal zone. The rocky oysters have a dedicated strip in the tidal zone, and the oyster origin in this area is located on the rocky surfaces (flat and vertical). The cause of these oysters' density may be the high algal density in the area that is used as molluscan food. One of the attractions of these shores is caves in the South and South West coast of the island. The collision of the waves has led to caves in the lower parts of these rocks and created beautiful views between the sea and the land border (Figure $13 \mathrm{a}, \mathrm{b}$ ). 


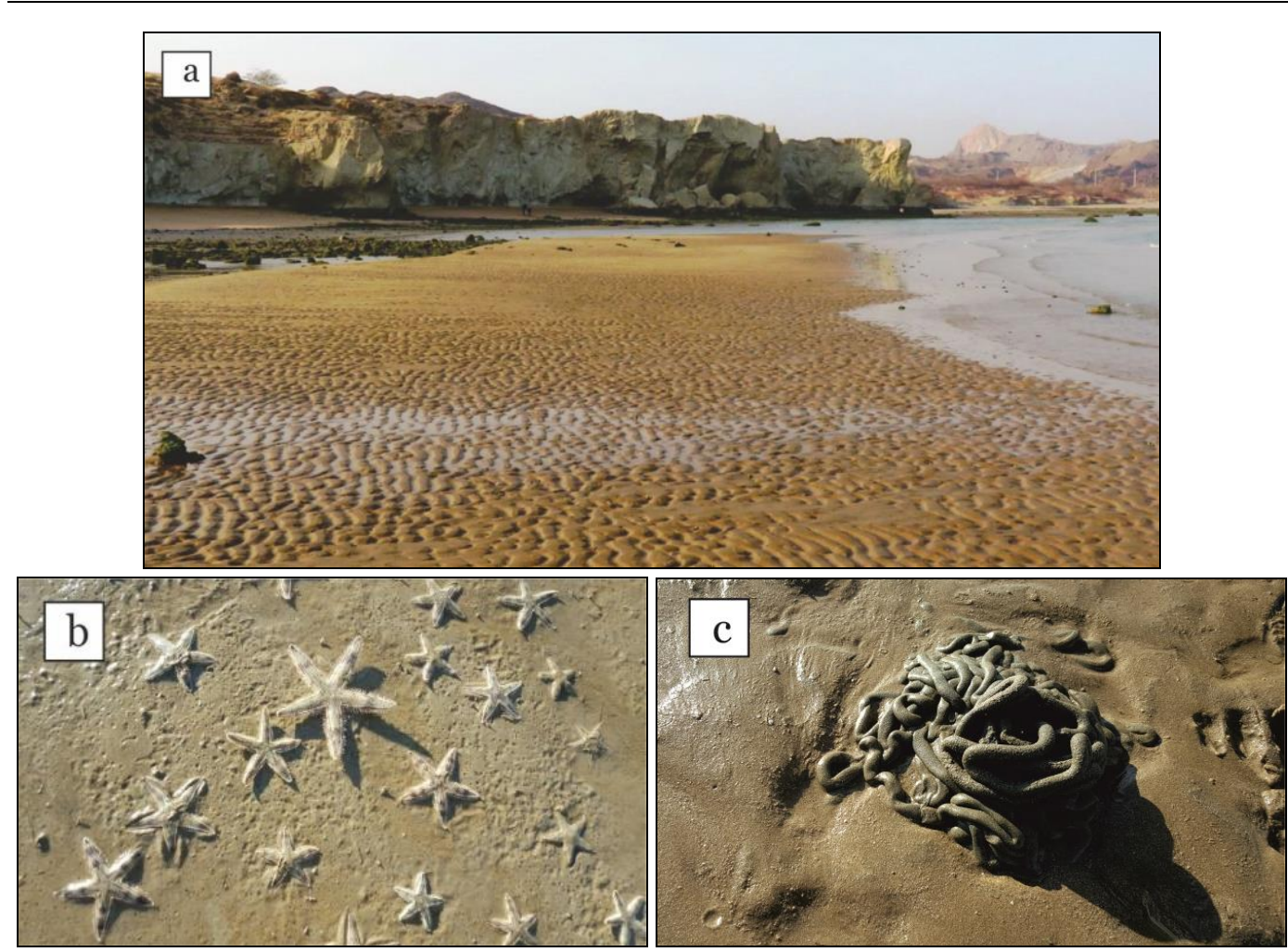

Figure 12. a) sandy beach in the eastern part of the island when tide time, b) a set of starfish on sandy beaches when tide occurs and c) Lugworm (Arenicola marina) casts on beach
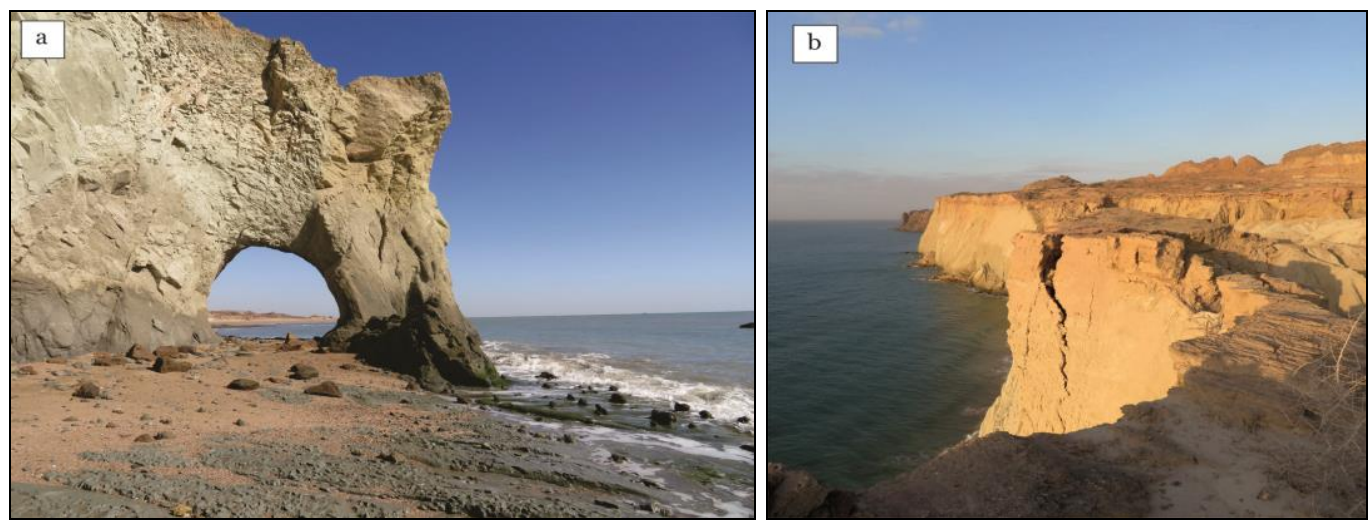

Figure 13. a, b) A rocky beach located on the eastern part of Hormuz Island

\section{Portuguese Castle}

In the northern most part of the island, the ruins of "Portuguese Castle" and its protruding nose are the most important historical monument of Hormuz. The Portuguese Castle of Hormuz Island incorporates the geotic, biotic, and anthropic aspects of the monument (Martínez-Torres, 2018). Portuguese castles are observed in many southern islands of Iran. It dates back to the governance of the Portuguese in the southern region of Iran. The materials used in the construction of the castle have been all from the 
mineral resources of the island. The castle is in the form of an irregular polygon. The main components of materials include volcanic rocks and residuals of beach rocks and coral skeletons. The Portuguese castle was constructed in June 1507 under the command of Alfonso de Albuquerque, an offensive Portuguese sailor on the northern side of Hormuz Island in the Persian Gulf. The Portuguese occupation of this important naval waterway lasted for 110 years. Over this time, they constructed fortifications and fortresses, such as the fortresses of Qeshm and Lark.

Later, The Imam-Quli Khan's soldiers with the help of the British navy, captured the Portuguese Castle at the Hormuz Island on April 1622. They expelled Portuguese from Hormuz castle and pulled down their flag. The Portuguese Castle in Hormuz Island includes weapon warehouses, large water cisterns, barracks rooms, prison, churches, command base and halls. Today, the remains and ruins of its buildings and balls in the north of the island are the examples for the invaders in Iran (Figure $14 \mathrm{a}, \mathrm{b}$ ).
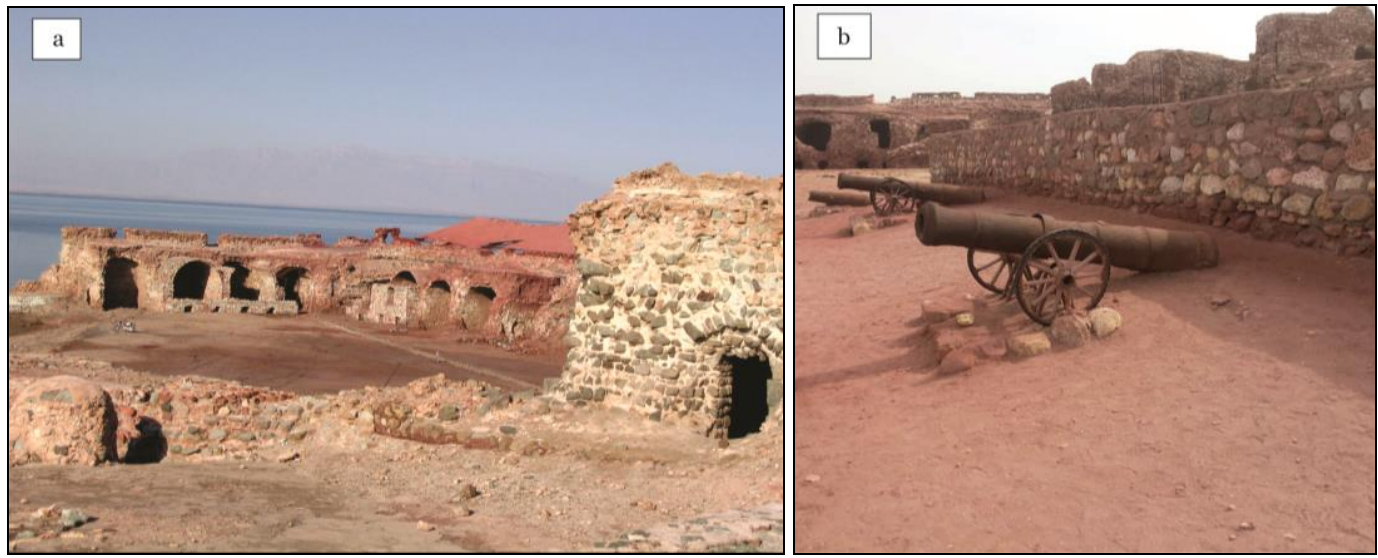

Figure 14. a) a view of the remains of the Portuguese Castle in the north of the island, b) the remained weapons of the portogese in the castle
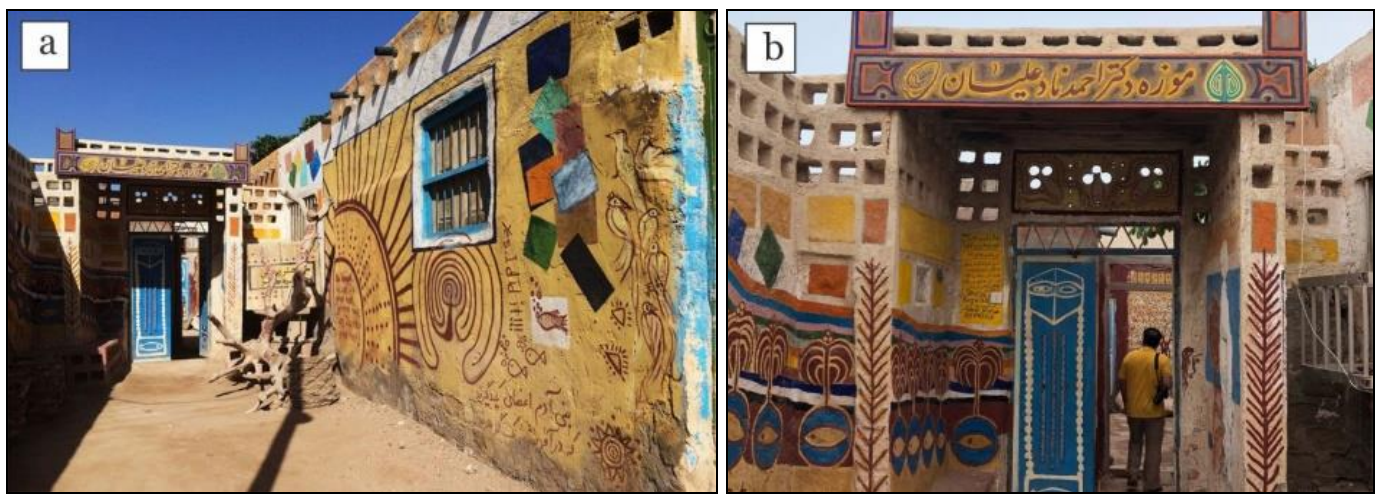

Figure 15. a, b) Entrance to Dr. Nadalian Museum near the Hormuz Island Harbor Port

\section{Dr. Nadalian Museum}

Dr. Nadalian Museum is located in the old part of Hormuz Island near the harbor. In this museum, you will get familiar with the native culture of the old urbanization of Hormuz. It is a permanent museum of environmental arts. Iranian and international artists have painted all the walls and surrounding area with colorful soils of Hormuz. Currently, 
there are many painting workshops on the island, where native women implement Ahmad Nadalian's designs using colored soils and the works are sold in the museum (Figure $15 \mathrm{a}, \mathrm{b}$ ).

\section{CONCLUSION}

Hormuz Island is one of the salt domes observed in southern Iran and in the Persian Gulf region. Considering the diversity of volcanic rocks, as well as the various alterations and mineralizations, a very attractive and colorful landscape was created on the island. Also, the coexistence of rocks with the beach as well as the dissolution of the red soils of the island has created amazing geotourism landscapes.

As Iran's geological paradise, Hormuz Island has the abundant potential for expanding the tourism industry, in particular, geotourism. Hence, for optimal use of this potential, and given the special advantages of the island as a geotourism center, due to its natural, ancient and geological attractions, there must be more fundamental works to solve some problems including the lack of facilities, security and health problems, and culturalization in the field of geotourism works among the native peoples of the region. So that, it will be possible to provide ideal social and the economic conditions for the region and the indigenous people of the island. Due to the unique area, variety of geosites, and suitable natural and cultural conditions, this island is prone to be a geopark. Geomorphologic examples of valley sculptures, as well as colored beaches, are one of the exceptional examples of the Hormuz Island.

\section{Aknowlegments}

The authors would like to acknowledge the University of Tehran for supports in the field works.

\section{REFERENCES}

Ahmadzadeh Heravi, M., \& Houshmandzadeh A, \& Nabavi, M., H. (1990). New concept of Hormuz formation's stratigraphy and the problem of salt diapirism in south Iran. In: Proceeding Symposium on Diapirism with Special Reference to Iran. Geological Survey of Iran, Tehran, p, 1-22.

Ala, M., A. (1974). Salt diapirism in Southern Iran. American Association of Petroleum Bulletin, 58(9), $1758-1770$.

Amrikazemi, A. (2002). Introducing Geotourism in Iran. In: 10th International Ecotourism Conference. Australia, Cairns.

Amrikazemi, A. (2004). Atlas of the Qeshm Geotourism, a look at the geological features of the Qeshm Island. Geological Survey of Iran.

Amrikazemi, A. (2009). Atlas of Geopark and Geotourism Resources of Iran. Geological Survey of Iran Publication, Tehran.

Amrikazemi, A. (2013). Geoheritage atlas of Iran. Geological Survey of Iran.

Amrikazemi, A., \& Mehrpooya, A. (2006). Geotourism resources of Iran. In: Dowling, Newsome D (eds) Geotourism: sustainability, impacts and management. Elsevier, Butterworth, p.78-92.

Aqanabati, S., A. (2006). Geology and Mineral Potential of Hormozgan Province. Journal of Development of Geology Training, 12, 4-11.

Bates, R.L., \& Jackson, J. A. (1980). Glossary of Geology. AGI, Falls Church, 751 p.

Bruthans, J., Filippi, M., Geršl, M., Zare, M., Melková, J., Pazdur, A., \& Bosák, P. (2006). Holocene marine terraces on two salt diapirs in Persian Gulf (Iran): age, depositional history and uplift rates. Journal of Quaternary Science, 21(8), 843-857.

Buschbaum, C., Lackschewitz, D., \& Reise, K. (2012). Nonnative macro benthos in the Wadden Sea ecosystem. Ocean Coast Manag 68, 89-101.

Dóniz-Páez, J., Becerra-Ramírez, R., González-Cárdenas, E., Cayetano Guillén-Martín, C., \& Escobar-Lahoz , E.(2011). Geomorphosites and geotourism in volcanic landscape: the example of LA CORONA DEL Lajial Cinder Cone (El Hierro, Canary Islands, Spain). GeoJournal of Tourism and Geosites, 2(8), $185-197$.

Dowling, R.K., \& Newsome, D. (2006) Geotourism. Elsevier, Oxford

Dowling, R.K.,(2010). Geotourism's global growth. Geoheritage, 3, 1-13. DOI: 10.1007/s12371-010- 0024-7.

Elyasi, J., Aminsobhani, E., Behzad, A., Moein Vaziri, H., \& Meysami, A. (1977). Geology of Hormoz Island. Proceeding of the Second Geological Symposium of Iran. The Iranian Petroleum Institute, Iran, p. 31-72 (in persian). 
Faramarzi, N.S., Amini, S., Schmitt, A., K., Hassanzadeh, J., Borg, G., McKeegan, K., Razavi, S., M., H., \& Mortazavi, S., M. (2015). Geochronology and geochemistry of rhyolites from Hormuz Island, southern Iran: A new record of Cadomian arc magmatism in the Hormuz Formation. Lithos, p. 203-211. http://dx.doi.org/10.1016/j.lithos.2015.08.017.

Ghasemi, S., Zakaria, M., Yusof, E., \& Danehkar, A. (2010). A review of mangrove value and conservation strategy by local communities in Hormozgan province, Iran. Journal of American Science, 6 (10), p. 329-338. http://dx.doi.org/10.1111/j.1365-2451.2008.00686.x.

Luttikhuizen, P. C., \& Dekker, R. (2010). Pseudo-cryptic species Arenicola defodiens and Arenicola marina (Polychaeta: Arenicolidae) in Wadden Sea, North Sea and Skagerrak: morphological and molecular variation. Journal of Sea Research, 63,17-23.

Martínez-Torres, L.M. (1994). Principales tipos de mapas geóticos [Main types of geotic maps]. Servicio Editorial de la Universidad del País Vasco, Bilbao.

Martínez-Torres, L.M. (2018). Geotourism based upon the Gothic Cathedral of Santa María, Vitoria-Gasteiz, Spain. GeoJournal of Tourism and Geosites, 22(2), 373-380. https://doi.org/10.30892/gtg.22208-295.

McKeever, P., \& Zouros, N., (2005), Geoparks: Celebrating Earth heritage, sustaining local communities: Episodes, v. 28, no. 4, pp. 274-278.

McKeever, P.J., Zouros, N., \& Patzak, M., 2010, The UNESCO Global Network of National Geoparks: The George Wright Forum, v. 27, no. 1, pp. 14-18.

Mirzabagheri, D., Amrollahi Biuki, N., \& Taheri Zadeh, M., R. (2018). Distribution pattern and a new coverage range index identification of zoanthids in littoral zone of Hormuz Island, Persian Gulf. Aquatic Ecology, 7(3), 9-24.

Moein Vaziri, H. (1996). An Introduction of Magmatism in Iran. University of Tarbiat Moalem Publication, Tehran (in persian).

Mortazavi, M., Heuss-Assbichler, S., \& Shahri, M. (2017). Hydrothermal systems in the salt domes of south Iran. Procedia Earth and Planetary Science 17, 913 - 916. doi: 10.1016/j.proeps.2017.01.016.

Newsome, D., \& Dowling R.K. (2010) Geotourism: the tourism of geology and landscape. Goodfellow Publishing Limited, p. 242.

Noori Koupaei, A., Ghavam Mostafavi, P., Jalil Fallah, M., \& Fatemi, S., M., R. (2014). Molecular diversity of coral reef-associated zoanthids off Qeshm Island, northern Persian Gulf. International Aquatic Research, 6:64 .doi. 10.1007/s40071-014-0064-8.

Noori-Koupaei, A., Ghavam-Mostafavi, P., Fallah-Mehrabadi, J., Fatemi, S., M., R., Noori-Koupaei, A., GhavamMostafavi, P., Fallah-Mehrabadi, J., Fatemi, S., M., R., \& Dehghani, H. (2015). Biodiversity of order Zoantharia in the Persian Gulf: Hormoz Island. Journal of Khoramshahr Marine Science and Technology, 14(1),31-40. (in Persian).

Samani, B., A. (1988). Metallogeny of the Precambrian in Iran. Precambrian Research, 39, 85-106.

Talaei Hassanlouei, B., \& Ali Rajabzadeh, A.M. (2018). Iron ore deposits associated with Hormuz evaporitic series in Hormuz and Pohl salt diapirs, Hormuzgan province, southern Iran. Journal of Asian Earth Sciences. https://doi.org/10.1016/j.jseaes.2018.08.024.

Talbot, C., J, Farhadi, R., \& Aftabi, P. (2009b). Potash in salt extruded at Sar Pohl diapir, Southern Iran. Ore Geology Reviews, 35, 352-366.

Talbot, C., J. (1998). Extrusions of Hormuz salt in Iran. Geological Society, London, Special Publications, 143, 315-334. https://doi.org/10.1144/GSL.SP.1998.143.01.21.

Talbot, C., J., Aftabi, P., \& Chemia, Z. (2009a). Potash in a salt mushroom at Hormuz Island Hormuz Strait. Iran. Ore Geology Reviews, 35, p. 317-332.

Waltham, T. (2008). Salt Terrains of Iran. Geology Today, 24, 188-194.

Yazdi, A., Arian, M.A., \& Tabari, M., M., R. (2014). Geological and Geotourism Study of Iran Geology Natural Museum, Hormoz Island. Open Journal of Ecology, 4, 703-714. http://dx.doi.org/10.4236/oje. 2014.411060.

Yazdi, A., Emami, M., H., \& Jafari, H., R. (2013). IRAN, the Center of Geotourism Potentials. Journal of Basic and Applied Scientific Research, 3,458-465.

Zahed, M., A., Ruhani, F., \& Mohajeri, S. (2010). An overview of Iranian mangrove ecosystem, northern part of the Persian Gulf and Oman Sea. Electronic Journal of Environmental, Agricultural and Food Chemistry, 9(2), 411-417.

Zakeri, H., \& Habib, F. (2013a). Ecotourism Development Strategy in Hormoz Island using SWOT Model. American Journal of Scientific Research, 90,38-47.

Zakeri, H., \& Habib, F. (2013b). Analyzing Factors Affecting Formation of Cultural Landscape in Hormoz Island. Advances in Environmental Biology, 7(6), 988-998.

Submitted:

06.04.2019
Revised:

19.02.2020
Accepted and published online

27.02.2020 